\title{
Experimental Study on High Strength Concrete using Industrial Wastes
}

\author{
Sriram R', Mr. Prabakaran², Mrs. Uma Nambi ${ }^{3}$ \\ 1PG Student, ${ }^{2}$ Assistant Professor, ${ }^{3} \mathrm{Head}$ of Department \\ 1,2Civil Engineering Department, Paavai Engineering College, Namakkal, Tamil Nadu, India
}

\begin{abstract}
How to cite this paper: Sriram $\mathrm{R} \mid \mathrm{Mr}$. Prabakaran | Mrs. Uma Nambi "Experimental Study on High Strength Concrete using Industrial Wastes" Published in International Journal of Trend in Scientific Research and Development (ijtsrd), ISSN: 24566470, Volume-3 | Issue-3, April 2019, pp.976-980, URL: https://www.ijtsrd.c om/papers/ijtsrd23155.pdf
\end{abstract}

Copyright (C) 2019 by author(s) and International Journal of Trend in Scientific Research and Development Journal. This is an Open Access article distributed under

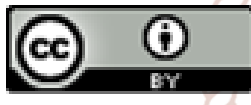
the terms of the Creative Commons Attribution License (CC BY 4.0) (http://creativecommons.org/licenses/ by/4.0)

\section{INTRODUCTION \\ 1.1 GENERAL}

Conventionally concrete is a mixture of cement, sand and aggregates. Properties of aggregate affect the durability and performance of concrete, so fine aggregate is an essential component of concrete. The most commonly used fine aggregate is natural river or pit sand. Fine and coarse aggregate constitute about $75 \%$ of total volume. It is therefore, important to obtain right type and good quality aggregate at site, because the aggregate form the main matrix of concrete or mortar. The global consumption of natural sand is very high due to the extensive use of concrete. In general, the demand of natural sand is quite high in developing countries to satisfy the rapid infrastructural growth. In this situation developing countries like India facing shortage in good quality natural sand. Particularly in India, natural sand deposits are being depleted and causing serious threat to environment as well as the society. Increasing extraction of natural sand from river bed causing many problems, loosing water retaining sand strata, deepening of the river courses and causing many bank slides, loss of vegetation on the bank of rivers, exposing the intake well of water supply schemes, disturbs the aquatic life as well as affecting the agriculture due to lowering the underground water table etc., are few examples. In past decade variable cost of natural sand used as fine aggregate in concrete increased the cost of construction. In this situation research began for inexpensive and easily available material to natural sand.

\subsection{CONCRETE}

Concrete is one of the most widely used construction materials throughout the world. Fresh concrete or plastic concrete is a freshly mixed material which can be moulded into any shape. The relative quantities of cement, aggregates and water mixed together, control the properties of concrete in the wet state as well as in hardened state.

There are two overall criteria of good concrete: the concrete has to be satisfactory in its hardened state and also in its fresh state while being transported from the mixer and placed in the formwork. The requirements in fresh state are that the consistency of the mix be such that it can be compacted by the means desired without excessive effort, and also that the mix must be cohesive enough for the methods of transporting and placing used so as not to produce segregation.

\subsection{GREEN SAND}


Ferrous and nonferrous metal casting industries produce several million tons of by-products in the world.WFS is a major byproduct of metal casting industry and successfully used as a land filling material for many years. But use of waste foundry sand (WFS) for land filling is becoming a problem due to rapid increase in disposal cost. In an effort to use the WFS in large volume, research is being carried out for its possible large scale utilization in making concrete as partial replacement of fine aggregate.

\subsection{MARBLE POWDER}

Marble has been commonly used as a building material since the ancient times. The industry's disposal of the marble powder material, consisting of very fine powder, today constitutes one of the environmental problems around the world. During the cutting process about $25 \%$ the original marble mass is lost in the form of dust. Marble dust can be used either to produce new products or as an admixture so that the natural sources are used more efficiently and the environment is saved from dumpsites of marble waste.

\subsection{METAKAOLIN}

Metakaolin is a dehydoxylated form of the clay mineral kaolinite. Stone that are rich in kaolinite are known as china clay or kaolin, traditionally used in the manufacture of porcelain. The particle size of metakaolin is smaller than cement particles, but not as fine as silica fume. Therefore, metakaolin is replaced for cement in this project.

\subsection{SCOPE AND OBJECTIVE OF THIS STUDY}

Concrete is a composite material which uses coarse aggregate, fine aggregate, cement as the ingredients to get a better texture for the structure. To get a economical concrete we have to use considerable amount of waste material. Thus in this study foundry sand, marble powder and Metakaolin are used which consists primarily of silica sand, coated with a thin film of burnt carbon, residual binder and dust.

The scope of this work is to study the fresh concrete properties, hardened concrete properties and also the micro structure study with the above alternative materials for river sand and for cement.

\subsection{LITERATURE REVIEW}

Zdenek P et al., (1988), studied the size effect in pull out test. The test specimen was a cube with a steel bar parallel to one edge of the cube and sticking out at the center of one face. To determine the size effect, geometrically similar specimens with cube sides $d=1.5,3$, and 6 in. (38.1, 76.2, and 152.4 $\mathrm{mm}$ ) were tested. Deformed reinforcing bars of yield strength $60,000 \mathrm{psi}(414 \mathrm{MPa}$ ) and diameters $0.113,0.25$, and $0.5 \mathrm{in} .(2.9,6.4$, and $12.7 \mathrm{~mm})$ scaled in proportion to the cube size were used. The embedment lengths of the steel bars were $0.5,1.0$, and 2.0 in. $(12.7,25.4$, and $50.8 \mathrm{~mm})$. The present test results on pullout of reinforcing bars from concrete confirmed that a size effect is present, i.e., the nominal shear bond stress at failure decreased as the specimen size increased. The experiments indicated that larger specimens, with larger bars, tend to fail in a more brittle, splitting mode, while smaller specimens, with smaller bars, tend to fail in a less brittle or more plastic shear-pullout mode. This transition in the type of failure as a function of specimen size has been in agreement with the physical implications of the size effect law and supported its applicability.
Ravindra Gettu et al., (1990), investigated the fracture properties and brittleness of high strength concrete. In this experiment, geometrically similar three-point bending specimens were tested and the measured peak load values were used to obtain the fracture energy, the fracture toughness, the effective length of the fracture process zone, and the effective critical crack-tip opening displacement. The concrete mix was designed to exceed a 28-day compressive strength of $83 \mathrm{MPa}$. Beam specimens of four different sizes, three in each size, were cast from the same batch of concrete. The specimens were $38 \mathrm{~mm}$ thick and 305, 152, 76, and 38 mm deep. Their lengths were 8/3 times their depths and their spans 2.5 times the depths. Before testing, a notch 2 mm wide was cut at the mid span of each beam using diamond band saw. The length of the notch was one-third the depth of the beam. The three-point bending test was used due to the relatively simple test setup and the impossibility of crack bifurcation. The test results from the largest beams were, however, excluded from the following analysis because their load values were inconsistent with the trend of the other tests. In retrospect, this inconsistency may be due to the difference in control parameters used for testing and in machine characteristics.

N. Banthia \& J. Shengb (1996) carried out their investigation in the fracture toughness of micro-fiber reinforced cement composites. Toughness and strength improvements in cement based matrices due to micro-fiber reinforcement were investigated. Cement paste and cement mortar matrices were reinforced at 1,2 and $3 \%$ by volume of carbon, steel and polypropylene microfibers, and these composites were then characterised in the hardened state under an applied flexural load. Both notched and unnotched specimens were tested in four-point bending. The test result showed that considerable strengthening, toughening and stiffening of the host matrix due to microfiber reinforcement was observed.

P.Aggarwal Y.Aggarwal (2007), investigated the effects of bottom ash as replacement of fine aggregate in concrete. Bottom ash was replaced from $20 \%$ to $50 \%$ and five mixes were made. It was reported that the Compressive strength at 90 days was found to be $108 \%$ to $105 \%$ of normal concrete, Flexural strength at 90 days was $113 \%$ to $118 \%$ of normal concrete, Split tensile strength at 90 days was $121 \%$ to $126 \%$ of normal concrete. The test results also indicated that the workability measured in terms of Compaction factor decreases with the increase in replacement levels of bottom ash.

Rafat Siddique et al., (2008), studied the Effect of usedfoundry sand on the mechanical properties of concrete. The experiment involved the replacement of fine aggregate with $10 \%, 20 \%$ and $30 \%$ of foundry sand. The results included the study of various fresh and hardened properties of concrete. Compressive strength, split tensile, flexural strength and modulus of elasticity were determined for 28 , 56, 91 and 356 days. All the characteristic strength increased with the increase in the foundry sand and also increased with the age. Increase in compressive strength varied between $8 \%$ and $19 \%$ depending upon UFS percentage and testing age, whereas it was between $6.5 \%$ and $14.5 \%$ for splitting-tensile strength, $7 \%$ and $12 \%$ for flexural strength, and $5 \%$ and $12 \%$ for modulus of Elasticity. It was found out from the test report that the used foundry sand could be conveniently used in making good quality concrete. 
P Sravana et al., (2009), investigated the Impact strength of high volume fly ash fibre concrete with fly ash as an additional material. The experimental investigations were carried out to study the impact strength of ordinary concrete and high volume fly ash concrete using 50 percent fly ash as an addition with different percentages of steel fibres' at 28 and 90 days. It was found out that the impact strength increased due to addition of steel fibres to high volume fly ash concrete. The ultimate impact strength of high volume fly ash concrete of $\mathrm{w} / \mathrm{b} 0.36$ with $1.5 \%$ steel fibres at 90 days increased by $50 \%$ with respect to ordinary concrete with $1.5 \%$ steel fibres. The Ultimate Impact Strength of high volume fly ash concrete with $1.5 \%$ steel fibres at 90 days increased to $400 \%$ with respect to without fibres.

Marco Valente (2012), studied the bond strength between corroded steel bars and concrete. Experimental tests of push-pull type using reinforcement bars embedded in concrete specimens and finite element analyses were carried out in order to investigate the effects of natural corrosion, confinement and repeated cyclic loading on bond between steel rebar and concrete. It is evident from the result that the conditions of the concrete cover and the corrosion state of the stirrups influenced the confinement, whereas the corrosion level of the longitudinal bar directly affected bond. In some cases the presence of an effective confinement prevented the formation of splitting cracks and high peak values of bond stress were achieved. In other cases a marked deterioration was observed at the outer surface of the concrete and considerable levels of corrosion were detected on the longitudinal bar.

\subsection{MATERIALS USED IN THE WORK \\ $>$ Cement \\ $>$ Fine aggregate \\ $>$ Coarse aggregate \\ $>$ Water \\ $>$ Metakaolin \\ $>$ Green sand \\ $>$ Marble powder \\ $>$ Superplasticizer}

\subsection{PRELIMINARY INVESTIGATION 1.10.1 PRELIMINARY TEST}

Under preliminary test, the properties of various ingredients used in concrete are studied.

\subsubsection{TEST FOR CEMENT}

$>$ Fineness Test

$>$ Normal Consistency

$>$ Initial Setting time

$>$ Final setting time

$>$ Specific gravity

1.10.3 TEST FOR FINE AGGREGATE

$>$ Fineness modulus

$>$ Specific gravity

1.10.4 TEST FOR COARSE AGGREGATE

$>$ Fineness modulus

$>$ Specific gravity

\subsubsection{CONCRETE MIX DESIGN}

\subsection{INDIAN STANDARD METHOD}

This mix design of M40 grade of concrete is done using IS 10262:2009 ny using the test results of the material known.

\subsection{DESIGN STIPULATION}

$>$ Characteristic compressive strength required in the field at 28 days $=30 \mathrm{~N} / \mathrm{mm} 2$

$>$ Maximum size of aggregate $\quad=20 \mathrm{~mm}$

$>$ Degree of quality control= Good

$>$ Type of exposure= Mild

Concrete mixture proportions such as Metakaolin (5\%) as cement replacement,

Green sand and marble powder (5\%, 10\%, 15\%, 20\%) as sand replacement with

$\mathrm{w} / \mathrm{c}=0.4$ was used. The mix proportion was shown in table 5.1.

Mix proportion $=1: 2.08: 3.57$

\subsection{TESTS DONE IN THIS PROJECT}

$>$ Fracture toughness test (three point and four point bending)

$>$ Shear strength test

$>$ Impact strength test

$>$ Pull out test

All the tests were carried out after 28 days of curing.

\subsection{TESTS FOR HARDENED CONCRETE}

\subsubsection{SHEAR STRENGTH TEST}

Based on the experimental investigation held by MK Maroliya, the shear specimens were taken as "L" shaped specimens as given in figure 6.1. The experimental setup was also shown. In order to distribute the shear load uniformly, a rod of $22 \mathrm{~mm}$ was placed above the specimen above where the load is applied. The test was done in Compression testing machine with the following apparatus setup given in figure 6.2
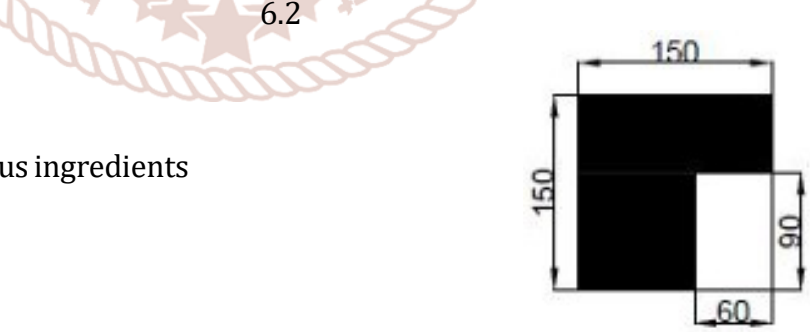

Figure 6.1 Detailing of shear specimen (All dimensions are in $\mathrm{mm}$ )

Table 6.1 Shear strength (28 days) for various mixes

\begin{tabular}{|c|c|c|}
\hline MIX ID & $\begin{array}{c}\text { ULTIMATE LOAD AT } \\
\text { FAILURE (kN) }\end{array}$ & $\begin{array}{c}\text { SHEAR STRENGTH } \\
\left(\mathbf{N} / \mathbf{m m}^{2}\right)\end{array}$ \\
\hline D1 & 390.67 & 4.340 \\
\hline D2 & 587 & 6.521 \\
\hline D3 & 594.67 & 6.681 \\
\hline D4 & 603.67 & 6.707 \\
\hline D5 & 567.67 & 6.307 \\
\hline
\end{tabular}

\subsubsection{IMPACT TEST}

Different guidelines have been suggested by various impact test methods such as projectile impact test, drop-weight test and explosive test and they may be used for the investigation of impact resistance of concrete. Among these test methods, 
the drop-weight test proposed by the ACI (American Concrete Institution) committee 544 is the simplest method for evaluating the impact strength of concrete.

The impact resistance of the specimens is to be determined in accordance with the procedure proposed by the ACI committee 544. For this purpose, three disc of size $15 \mathrm{~mm}$ diameter and $63.5 \mathrm{~mm}$ in height was prepared using PVC pipes. After concreting under a flat surface, they are to be cured for 28 days. During testing of the specimens, they are to be placed on the base plate of impact testing machine and then struck with repeated blows. The impact load has to be applied with a $44.5 \mathrm{~N}$ hammer dropped repeatedly from a $457 \mathrm{~mm}$ height on to a $63.5 \mathrm{~mm}$ steel ball, which was loaded at the center of the top surface of the disc.

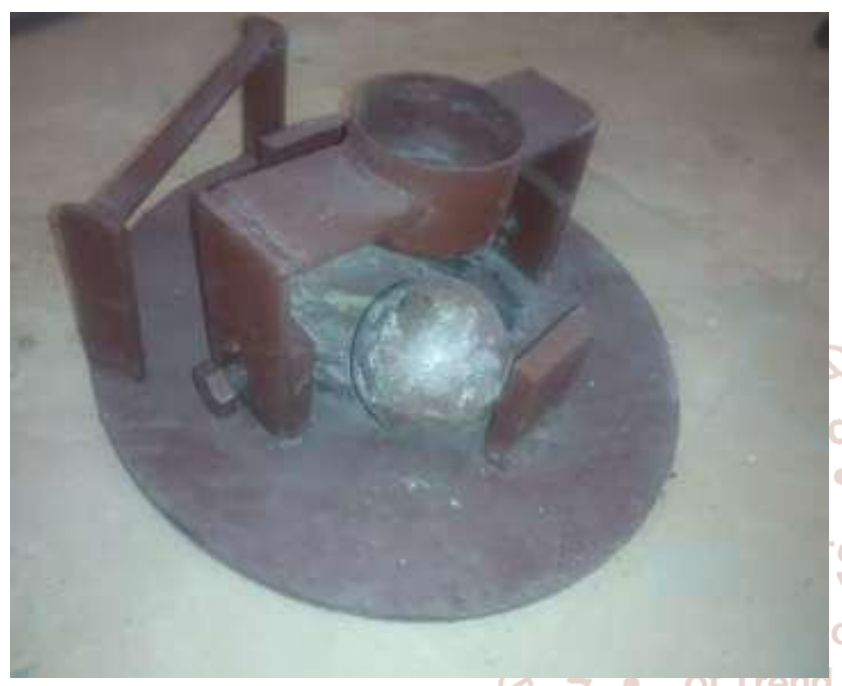

Figure 6.5 Impact Test Apparatus

In each test, the number of blows (N1) required to produce the initiation of cracks will be recorded as the initial crack strength and the number of blows (N2) that cause complete failure of the specimen will be recorded as the facture strength of the specimen. The energy absorption capacity of each specimen used in this test will be calculated from the following equation.

Impact Energy $\mathrm{U}=(\mathrm{nmV} 2 / 2)$

where,

$\mathrm{U}=$ absorbed energy

$\mathrm{n}=$ number of impacts

$\mathrm{m}=$ drop mass

$\mathrm{V}=$ impact velocity

\begin{tabular}{|c|c|}
\hline MIX ID & IMPACT ENERGY (kNmm) \\
\hline D1 & 28.33 \\
\hline D2 & 31.982 \\
\hline D3 & 33.93 \\
\hline D4 & 29.35 \\
\hline D5 & 27.05 \\
\hline
\end{tabular}

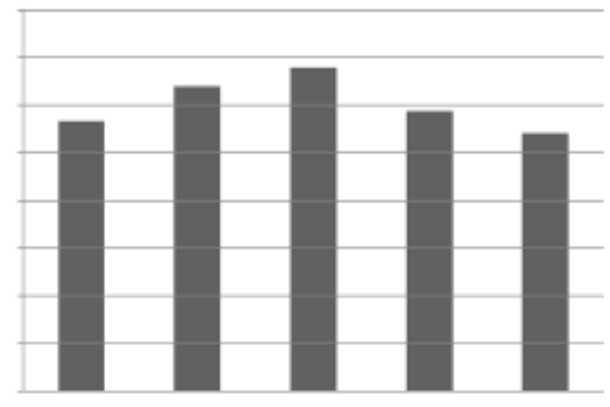

Impact Energy of the specimen at 28 days

\subsection{RESULTS AND DISCUSSIONS}

$>$ Use of green materials in the concrete mix resulted in the lowering of strength gaining capacity because of the addition and proportions of various materials.

$>$ From fig 6.4, it has been found that the shear strength of the specimens was found to be higher at D4 mix and then it started decreasing. It is also noted that there was not much variations in the strength gain which approximately resulted in equal values

$>$ From fig 6.6, the impact energy of the specimens is maximum at D3 and then the curve starts decreasing gradually.

From fig 6.7, the pull out strength of the specimens gained its maximum strength at D4.

From table 6.4, it has been inferred that there was not much gain of strength in the fracture toughness. This may be due to the non-addition of steel fibers to check the fracture toughness properties.

\subsection{CONCLUSION}

$>$ The alternative material for cement added here is Metakaolin which is an industrial by product and finds a threat to environment due to its disposal problems. Incorporating as a replacement for cement would result in reducing the disposal problems.

4 From the results obtained from various tests, there is an increase of strength gain from the control mix.

- The strength gain was up to $15 \%$ replacement of river sand and $5 \%$ replacement of cement.

> When river sand is replaced for $20 \%$, there results in decrease of strength which may be due to the excessive addition of green sand and marble powder in which both are water absorbing materials and also due to the addition of Metakaolin.

$>$ The fracture toughness properties was very poor eventhough the green materials are added. This may be due to the absence of steel fibers which is mainly responsible for the increase in strength in fracture toughness.

\subsection{REFERENCES}

[1] Aggarwal P, Aggarwal Y, Gupta S M (2007), "Effect of bottom ash as replacement of fine aggregates in concrete", Asian journal of civil engineering (building and housing), Vol. 8, pp. 49-62.

[2] Banthia N\&Shengb J (1996), "Frature toughnessof micro-fiber reinforced cement composites", Cement and concrete composites 18, pp. 251-269.

[3] Bhuvaneshwari P and Murali R (2013), "Strength characteristics of glass fibre on bottom ash based concrete", International Journal of Science, Environment and Technology, Vol. 2, pp. 90 - 102. 
[4] Ganeshram and Gopalan (2015), "An Experimental Study on Impact Strength of Self Compacting Concrete", International Journal of Engineering Research \& Technology (IJERT), Vol. 4.

[5] Govindarajan D, Keerthana M, Kumara raja G, Prasanna Kumar R (2014), "Experimental Investigation on Replacement of Fine Aggregate with Bottom Ash in Concrete", International Journal of ChemTech Research CODEN (USA): IJCRGG, Vol.6, pp 5570-5574.

[6] Gurpreet Singh, and Rafat Siddique (2012), "Effect of waste foundry sand (WFS) as partial replacement of sand on the strength, ultrasonic pulse velocity and permeability of concrete", Construction and Building Materials, pp.416-422.

[7] Marco Valente (2012), "Bond Strength between Corroded Steel Rebar and Concrete",IACSIT International Journal of Engineering and Technology, Vol. 4.

[8] Maria Teresa Gomes Barbosa \& Souza Sánchez Filho (2013), "Investigation of Bond Stress in Pull Out Specimens with High Strength Concrete", Global Journal of Researches in Engineering Civil And Structural Engineering, Vol.13.

[9] Mathiraja C (2013), "Mechanical Properties of concrete using bottom ash and M.Sand", International Journal of Latest Trends in Engineering and Technology (IJLTET), Vol. 3.

[10] Nova John (2013), "Strength Properties of Metakaolin Admixed Concrete", International Journal of Scientific and Research Publications, Vol.3.

[11] Patil1 B B, Kumbhar P D (2012), "Strength and Durability Properties of High Performance Concrete incorporating High Reactivity Metakaolin", International Journal of Modern Engineering Research (IJMER) Vol.2, pp-1099-1104.

[12] Rafat Siddique, Geert de Schutter, Albert Noumowe (2008), "Effect of used-foundry sand on the mechanical properties of concrete", Construction and Building Materials 23 (2009), pp. 976-980.
[13] Ramesh K, Dr.Arunachalam K, Rooban Chakravarthy S (2013), "Experimental Investigation on Impact Resistance of Flyash Concrete and Flyash Fiber Reinforced Concrete", International Journal of Engineering Research and Applications (IJERA),Vol. 3, pp.990-999.

[14] Ravindra Gettu, Zdenek P Balant, and Martha E Karr (1990), "Fracture Properties and Brittleness of HighStrength Concrete", ACI Materials Journal.

[15] Remya Raju, Mathews M Paul\& Aboobacker KA (2014), "Strength performance of concrete using bottom ash as fine aggregate", International Journal of Research in Engineering \& Technology (IMPACT: IJRET),Vol. 2.

[16] Sanjay N Patil, Anil KGupta, Subhash S Deshpande (2013), "Metakaolin-Pozzolanic Material For Cement in High Strength Concrete", IOSR Journal of Mechanical and Civil Engineering (IOSR-JMCE), pp: 46-49.

[17] Shetty M S (2012), "Concrete technology Theory and Practice", S. Chand \& Company Ltd.

[18] Sravana P, Srinivasa Rao P, Viswanadham M, Seshagiri Rao M V, Seshadri Sekhar T (2009) "Impact strength of high volume fly ash fibre concrete with high volumes of fly ash as an additional material". 34thConference on our world in concrete \& structures: 16 - 18 August 2009, Singapore.

[19] Dr.Srinivasu K, Krishna Sai M L N, Venkata Sairam Kumar.N (2014), "A Review on Use of Metakaolin in Cement Mortar and Concrete", International Journal of Innovative Research in Science, Engineering and Technology,Vol.3.

[20] Tumingan, Tjaronge M W, Rudy Djamaluddin and Victor Sampebulu (2014), "Compression strength of concrete with pond ash as replacement of fine aggregate", ARPN Journal of Engineering and Applied SciencesVol. 9.

[21] Zdenek P Bazant and Slddlk Sener (1988), "Size Effect in Pullout Tests", ACI Materials Journal. 